\title{
Prospective Open-Label Study of 48-Week Subcutaneous Administration of Mepolizumab in Japanese Patients With Severe Eosinophilic Asthma
}

\author{
Kurosawa M, Sutoh E \\ Department of Allergy and Respiratory Medicine, Sutoh Hospital, Annaka, Gunma, Japan \\ J Investig Allergol Clin Immunol 2019; Vol. 29(1): 40-45 \\ doi: 10.18176/jiaci.0285
}

\begin{abstract}
Background: The long-term efficacy and safety of mepolizumab in patients with severe eosinophilic asthma has been evaluated in large-scale double-blind placebo-controlled trials. However, a prospective open-label trial of long-term subcutaneous administration of mepolizumab has not been performed in Japanese patients with severe eosinophilic asthma.

Methods: This study was a prospective, 48-week, open-label trial in 32 Japanese patients with severe eosinophilic asthma who received subcutaneous mepolizumab 100 mg every 4 weeks. Nine patients required oral corticosteroids daily despite receiving high-dose inhaled corticosteroids. Six patients had aspirin-exacerbated respiratory disease.

Results: All patients took mepolizumab throughout the study period. No patients experienced adverse events during the treatment. None of the patients experienced asthma exacerbations during the trial. In fact, forced expiratory volume in 1 second increased significantly at 24 weeks $(P<.01)$ and at 48 weeks $(P<.05)$. The peripheral blood eosinophil count in peripheral blood decreased after the first administration of mepolizumab in all patients and remained low until week 48. After starting mepolizumab, all oral corticosteroid-dependent asthmatics successfully withdrew corticosteroids without exacerbations and experienced a sustained reduction in peripheral blood eosinophil count. Blood levels of thymus and activation-regulated chemokine and IgE remained unchanged after 48 weeks of therapy with mepolizumab. Conclusion: This first prospective open-label pilot study in Japan demonstrated the long-term efficacy and safety of mepolizumab in patients with severe eosinophilic asthma.
\end{abstract}

Key words: Anti-IL-5 antibody. Eosinophilic asthma. Mepolizumab. Prospective open-label study. Thymus and activation-regulated chemokine.

\section{Resumen}

Introducción: La eficacia y seguridad a largo plazo de mepolizumab se ha evaluado mediante grandes estudios doble-ciego controlados con placebo. Sin embargo, no hay estudios prospectivos abiertos a largo plazo que analicen la administración de mepolizumab en pacientes japoneses con asma eosinofílica grave.

Métodos: Es un estudio prospectivo, abierto, de 48 semanas de duración en 32 pacientes japoneses con asma eosinofílica grave y que recibieron la administración subcutánea de $100 \mathrm{mg}$ de mepolizumab cada 4 semanas. Nueve pacientes necesitaban esteroides orales a diario a pesar del uso de altas dosis de corticoides inhalados. Seis pacientes tenían intolerancia respiratoria a Aspirina.

Resultados: Ningún paciente fue retirado del estudio ni tuvo efectos adversos durante el tratamiento. Ningún paciente tuvo exacerbaciones asmáticas durante el periodo del estudio. El volumen expirado máximo en el primer segundo aumentó de forma significativa en la semana $24(p<0,01)$ y en la semana $48(p<0,05)$. El número de eosinófilos en sangre periférica se redujo tras la primera administración de mepolizumab en todos los pacientes y continuó hasta la semana 48. Después del comienzo de la administración de mepolizumab a todos los pacientes con necesidad de esteroides orales se les retiraron sin que tuvieran posteriormente exacerbaciones y en paralelo a la disminución de eosinófilos en sangre periférica. Los niveles séricos de la quemoquina tímica de regulación y activación ni de lgE cambiaron en las 48 semanas del estudio.

Conclusión: Es el primer estudio piloto abierto y a largo plazo realizado en Japón que muestra la eficacia y seguridad de mepolizumab en pacientes con asma eosinofílica grave.

Palabras clave: Anticuerpo anti-IL5. Asma eosinofílica. Mepolizumab. Estudio prospectivo abierto. Quemoquina tímica de regulación y activación. 


\section{Introduction}

Eosinophils are major effector cells in bronchial asthma [1]. Overexpression of interleukin (IL) 5 has been demonstrated in patients with a variety of eosinophil-associated disorders, including bronchial asthma [2]. Mepolizumab is a humanized $\mathrm{IgG}_{1}$ monoclonal antibody that blocks human IL-5 from binding to the IL-5 receptor [3]. It was the first biological anti-IL-5 drug tested in randomized clinical trials on bronchial asthma, although it did not inhibit biphasic asthmatic response or airway hyperresponsiveness in an antigen inhalation study [4]. Subsequent clinical studies focusing on blood eosinophil count and based on symptom scores and lung function showed that mepolizumab was an effective treatment that reduced the risk of asthma exacerbations in patients with severe eosinophilic asthma $[5,6]$.

While no gold standard test is currently available to evaluate systematic control of asthma, the Asthma Control Test (ACT) [7] is often applied. In fact, symptom scores were significantly improved with mepolizumab in multicenter, double-blind, placebo-controlled trials $[5,6]$.

Data on the effects of mepolizumab on forced expiratory volume in 1 second $\left(\mathrm{FEV}_{1}\right)$ are contradictory: some studies indicated a modest increase in $\mathrm{FEV}_{1}$ with mepolizumab [6,8], whereas others showed that $\mathrm{FEV}_{1}$ did not improve $[4,5,9,10]$. One reason for the discrepancy may be differences in disease severity. In fact, one study evaluated the safety and efficacy profile of mepolizumab in patients receiving medium-dose inhaled corticosteroids [9].

InNovember 2015, the US Food and DrugAdministration(FDA) approved mepolizumab for use in patients aged $\geq 18$ years with severe eosinophilic asthma at a dose of $100 \mathrm{mg}$ to be administered subcutaneously once every 4 weeks [11]. In December 2015, the European Medicines Agency (EMA) approved a marketing authorization for mepolizumab that was valid throughout the European Union as a medicine under additional monitoring [12]. In June 2016, mepolizumab was first marketed in Japan for use in patients with severe eosinophilic asthma aged $\geq 12$ years.

Only 1 paper has reported data on the clinical efficacy and safety of mepolizumab in Japanese patients [13]. The study was a subanalysis of 50 Japanese patients in a global randomized, double-blind, double-dummy, 32-week trial known as Mepolizumab Adjunctive Therapy in Subjects with Severe Uncontrolled Refractory Asthma (MENSA) [6]. Mepolizumab was also assessed in COSMOS, a 52-week, open-label extension study in patients who received mepolizumab or placebo in MENSA or in the Steroid Reduction with Mepolizumab Study (SIRIUS). [14]. Ours is the first prospective open-label pilot study of 48-week subcutaneous administration of mepolizumab in Japanese patients with severe eosinophilic asthma under treatment with high-dose inhaled corticosteroids/long-acting $\beta_{2}$-agonist inhalers. The primary objective of this study was to investigate whether our results were consistent with the results of large-scale doubleblind placebo-controlled studies. In addition, we measured blood levels of thymus and activation-regulated chemokine (TARC) as a potential specific biomarker for the treatment of mepolizumab in severe eosinophilic asthma.

\section{Patients and Methods}

\section{Patients}

The study population comprised 32 patients (16 men and 16 women). Median age was 68.0 years (range, 27-87 years) in men and 57.9 years (range, 39-80 years) in women. The diagnosis of bronchial asthma was confirmed based on the Global Initiative for Asthma (GINA) guidelines [15]. Patients were required to have received a clinical diagnosis of bronchial asthma by experienced pulmonologists. $\mathrm{FEV}_{1}$ measured with a spirometer was less than $80 \%$ of the predicted value for age, sex, and height, with documented short-acting $\beta_{2}$-agonist reversibility of $>12 \%$ after administration of $180 \mu \mathrm{g}$ of albuterol (salbutamol). Nine patients ( 3 males and 6 females) had been receiving maintenance treatment with oral corticosteroids ( 5 to $10 \mathrm{mg}$ per day of prednisone or its equivalent) for at least 6 months before entering the study. Six patients $(3 \mathrm{men}$ and 3 women) had aspirin-exacerbated respiratory disease (AERD, also known as aspirin-intolerant asthma), which was diagnosed based on criteria reported elsewhere [16]. The clinical characteristics of the patients are shown in the Table.

All patients had to have experienced at least 2 asthma exacerbations in the previous year that were treated with systemic corticosteroids administered intravenously or orally for more than 3 days or that required a visit to the emergency department and/or hospitalization. They were receiving treatment with high-dose inhaled corticosteroids $(>500 \mu \mathrm{g}$ fluticasone dry powder or equivalent daily dosage/long-acting $\beta_{2}$-agonist inhalers) with an additional controller for 12 months before enrollment. In addition, all patients had to have an eosinophil count $\geq 150 / \mu \mathrm{L}$ in blood at screening or $\geq 300 / \mu \mathrm{L}$ at some time during the previous year. Patients were allowed to continue their current antiasthma therapy throughout the study. The exclusion criteria included present smoking, a past history of smoking greater than 10 pack-years, parasitic infection in the 6 months before study entry, substantial uncontrolled comorbidity, possibility of pregnancy, and history of poor treatment adherence.

Mepolizumab $100 \mathrm{mg}$ was administered subcutaneously at baseline (visit 1, week 0) and then every 4 weeks for a total of 44 weeks as an add-on to appropriate standard care that could be adjusted at the physician's discretion. Thirteen visits were completed up to 48 weeks. Patients were asked about

Table. Clinical Characteristics of the Study Patients

\begin{tabular}{lcc}
\hline Gender & Male & Female \\
\hline Number of patients & 16 & 16 \\
Median age, y & 68.0 & 57.9 \\
Type: Allergic & 10 & 8 \\
$\quad$ Nonallergic & 6 & 8 \\
Oral corticosteroid-dependent & 3 & 6 \\
Aspirin hypersensitivity (AERD) & 3 & 3 \\
\hline
\end{tabular}

Abbreviation: AERD, aspirin-exacerbated respiratory disease. 
exacerbations at every 4 -week visit from baseline to week 48 (exit visit).

Safety was evaluated at each visit based on adverse events, vital signs, and electrocardiographic findings, along with clinical laboratory test data at baseline (week 0) and at weeks 24 and 48. Blood eosinophil count was assessed at baseline and every 4 weeks until week 48 . FEV ${ }_{1}$ was measured at baseline and at weeks 24 and 48 (exit visit).

This study was performed in accordance with Good Clinical Practice guidelines and the ethics principles outlined in the Declaration of Helsinki 2008 and approved by the Institutional Ethics Committee of Sutoh Hospital (IRB\#20160049). Written informed consent was obtained from each patient before the study commenced. This study was conducted between June 2016 and January 2018.

\section{Clinical Measurements}

The percentages of predicted $\mathrm{FEV}_{1}$ were measured using a spirometer (FUKUDA-77, Fukuda Denshi), and the best of 3 expirations was recorded. The predicted values of $\mathrm{FEV}_{1}$ were calculated using published equations [17,18]. Eosinophils in peripheral blood were counted automatically using a counter (Beckman Coulter) and the MAXM A/L system (Beckman Coulter). Serum levels of total IgE were measured using the CAP system (Phadia), and the plasma concentration of TARC was assessed using enzyme-linked immunosorbent assay (R\&D Systems), as reported elsewhere [19].

\section{Statistical Analysis}

Data are presented as mean (SD) or numbers of observations, unless stated otherwise. Differences in study variables over time were analyzed using the Dunnett multiple comparison test. All statistical analyses were performed using Microsoft Excel for Mac 2011. A $P$ value $<.05$ was considered significant.

\section{Results}

No patients failed to continue treatment with mepolizumab because of adverse events, such as local injection site reactions and anaphylactic reactions. No patients complained of headache or signs of nasopharyngitis. No clinically relevant trends were observed in vital signs, electrocardiographic findings, or clinical laboratory test data. All patients continued to receive mepolizumab throughout the trial period, with no severe asthma exacerbations, defined as a worsening of asthma requiring systemic corticosteroids administered intravenously or orally or a visit to the emergency department and/or hospitalization. Mean $\mathrm{FEV}_{1}$ at weeks 24 and 48 was $72.7 \%$ $(10.0 \%)$ and $72.3 \%(9.1 \%)$, respectively, that is, a significant increase compared with $69.4 \%(11.8 \%)$ at baseline $(P<.01$ at week 24 and $P<.05$ at week 48) (Figure 1). Other measurements indicated that blood eosinophil counts showed a rapid (at week 4$)$ and sustained reduction $(P<.01)$ after 48 weeks of mepolizumab (Figure 2). In the present study, 9 patients required daily oral corticosteroid therapy before starting the trial, and all of the patients successfully withdrew from daily use of oral corticosteroids without exacerbations and in parallel

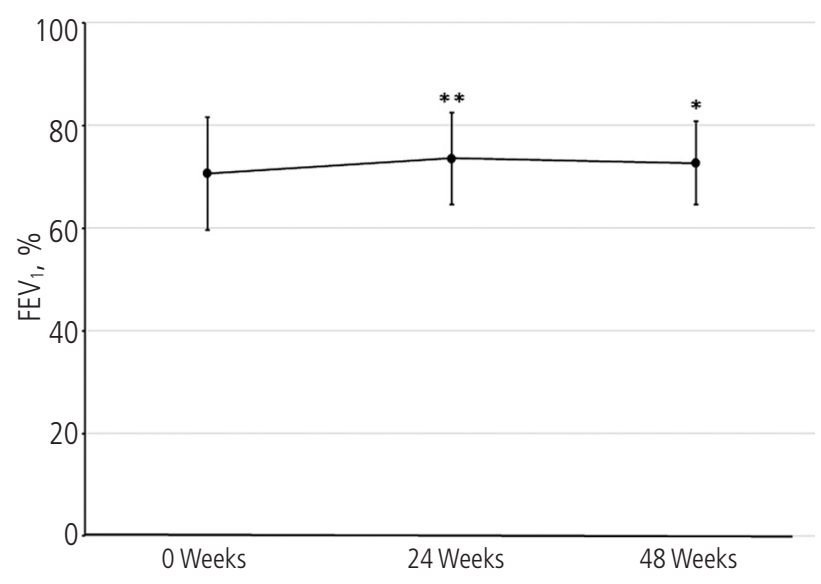

Figure 1. Change in forced expiratory volume in 1 second $\left(\mathrm{FEV}_{1}\right)$ before mepolizumab therapy (week 0) and at weeks 24 and 48 after the start of therapy. A significant improvement in $\mathrm{FEV}_{1}$ was seen at weeks 24 and 48. ${ }^{*} P<.05 ;{ }^{*} P<.01$.

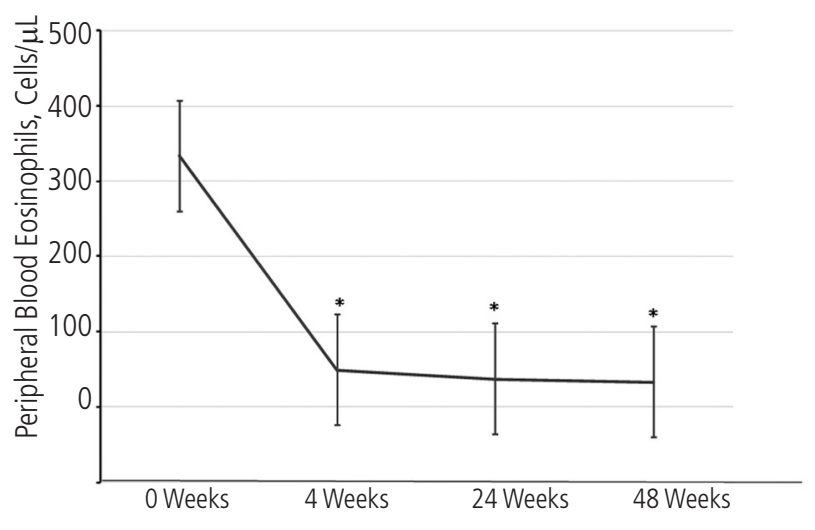

Figure 2. Change in peripheral blood eosinophil count before mepolizumab therapy (week 0) and at weeks 4, 24, and 48 after initiation of therapy. $A$ rapid and sustained significant reduction in peripheral blood eosinophil count was seen at weeks 4,24 , and 48 . ${ }^{\star} P<.01$.

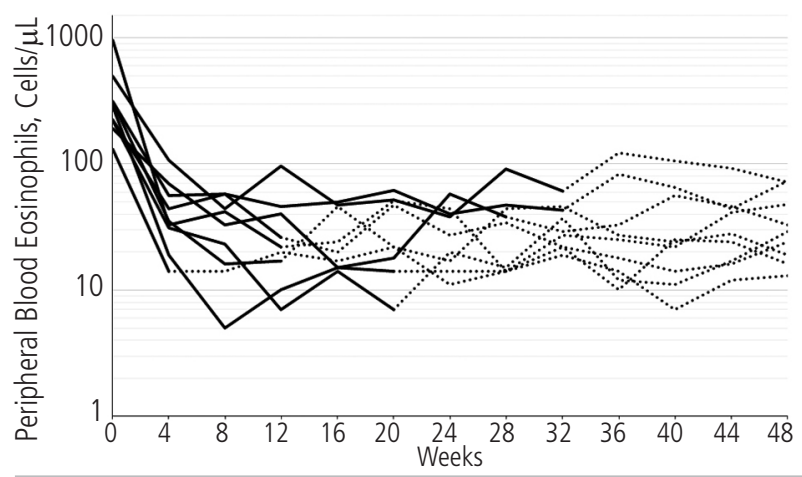

Figure 3. Change in peripheral blood eosinophil count in oral corticosteroid-dependent asthma patients before therapy with mepolizumab (week 0) and every 4 weeks thereafter. Solid lines show the eosinophil count under corticosteroid administration, and dotted lines show the eosinophil count without corticosteroids. All of 9 corticosteroiddependent asthma patients successfully withdrew daily use of oral corticosteroids, without exacerbations and in parallel with a sustained reduction in peripheral blood eosinophil count after initiation of therapy. 


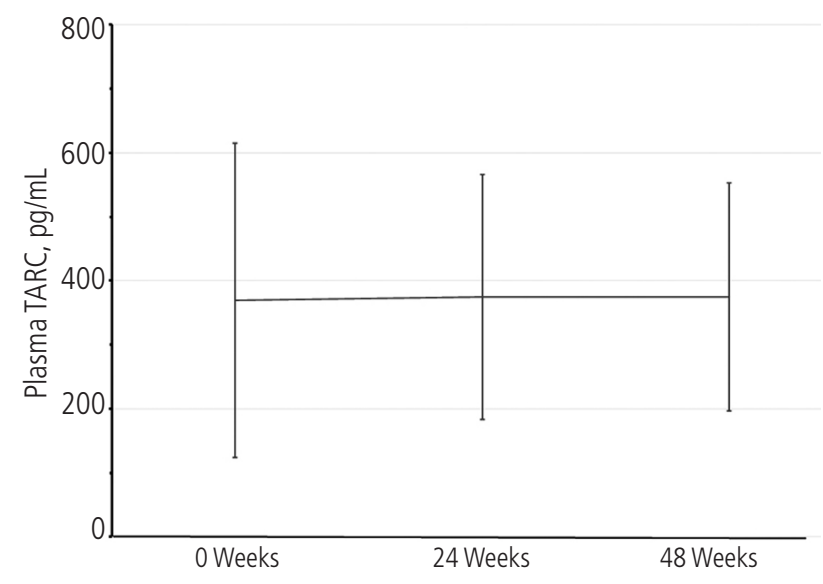

Figure 4. Change in plasma thymus and activation-regulated chemokine (TARC) levels before initiation of mepolizumab (week 0) and at weeks 24 and 48 after the start of the therapy. Mepolizumab showed no significant effect on plasma TARC levels.

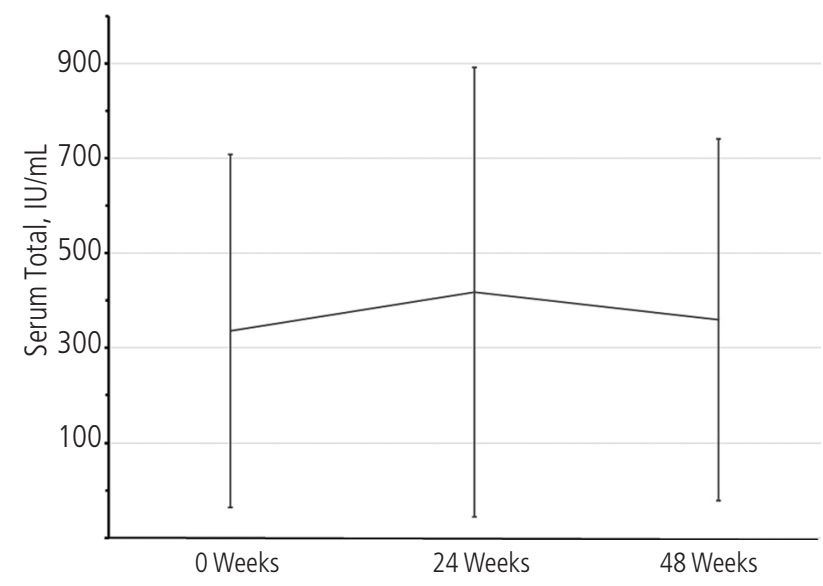

Figure 5. Change in serum total lgE levels before initiation of mepolizumab (week 0) and at weeks 24 and 48 after the start of the therapy. Mepolizumab showed no significant effect on serum total lgE levels.

with sustained reduction in peripheral blood eosinophil count after initiation of therapy (Figure 3). On the other hand, no changes were observed in peripheral blood levels of TARC and IgE after 48 weeks of mepolizumab (Figures 4 and 5).

\section{Discussion}

This was the first long-term, open-label pilot study of subcutaneous administration of mepolizumab in 32 Japanese patients with severe eosinophilic asthma treated with high-dose inhaled corticosteroids/long-acting $\beta_{2}$-agonists with or without oral corticosteroids. No patients experienced exacerbations during their 48-week course of mepolizumab. In fact, a significant increase in $\mathrm{FEV}_{1}$ was observed at weeks 24 and 48. Therefore, after 48 weeks, all of the patients continued treatment with mepolizumab.

The ACT [7] is often used to assess asthma control. However, it is based mainly on self-reported data, and the presence of rhinitis heavily affects the patient's perception of asthma control [20,21]. Rhinitis has been associated with an incremental adverse impact on disease-specific quality of life in asthmatic patients [20]. As rhinitis may affect the patient's perception of asthma, it was recently suggested that the accuracy of the ACT has not been systematically evaluated [22]. In 2015, the UK National Institute for Health and Care Excellence (NICE) issued a draft guideline recommending use of spirometry first to improve the diagnosis of asthma [23]. While the guidelines recommend spirometry as the first-line investigation, asthma should not be followed up on the basis of any single diagnostic test.

A recent review reported that blood eosinophil counts could be a predictive biomarker for the efficacy of treatment with mepolizumab in patients with severe eosinophilic bronchial asthma [24]. Therefore, we assessed peripheral blood eosinophil counts as our second endpoint. We observed a rapid and pronounced reduction in peripheral blood eosinophil levels in all patients after therapy with mepolizumab. This finding was consistent with data from previous studies $[4,5,9,24]$.

We also evaluated the corticosteroid-sparing effect of mepolizumab, because 9 patients required daily use of oral corticosteroids before initiating mepolizumab. All of the patients successfully took daily oral corticosteroids without exacerbations and in parallel with a sustained reduction in peripheral blood eosinophil count, which was consistent with the results of a previous report [25].

There has been growing interest in the identification of other potentially useful biomarkers for the management of bronchial asthma. A frequently used option is fractional exhaled nitric oxide (FeNO), in which levels have been reported to be closely associated with airway eosinophil counts [26]. However, data remain controversial [27], and a very recent paper indicated that FeNo measurement is not essential for asthma screening [28]. In fact, no significant differences in FeNO values were detected in the Dose Ranging Efficacy and Safety with Mepolizumab (DREAM) trial [5], indicating that FeNO is not a specific molecular biomarker for treatment with mepolizumab.

Bronchial asthma is a chronic inflammation of the airways involving mainly eosinophils and $\mathrm{T}$ cells. $\mathrm{CD} 4^{+} \mathrm{T}_{\mathrm{H}} 2$ cells produce cytokines such as IL-4, Il-5, and IL-13, which induce production of $\mathrm{IgE}$ and activation of eosinophils. TARC has been identified as a specific ligand for $\mathrm{CC}$ chemokine receptor 4 and was shown to induce chemotaxis of $\mathrm{CD}^{+} \mathrm{T}_{\mathrm{H}} 2$ cells [29], suggesting possible involvement of TARC in the pathogenesis of bronchial asthma. In fact, increased levels of TARC in the peripheral blood and sputum of asthmatics has been reported $[19,30,31]$. In addition, corticosteroid treatment decreased plasma TARC levels in asthmatics [19]. It also decreased bronchial epithelial TARC expression, which was associated with a reduction in eosinophil counts and $\mathrm{CD}^{+} \mathrm{T}_{\mathrm{H}} 2$ cell infiltration in asthma [32], suggesting that TARC may be a useful marker of bronchial asthma. However, to our knowledge, there have been no reports on the effect of mepolizumab on plasma TARC levels. Therefore, as the last endpoint of this study, we investigated the effects of mepolizumab on peripheral blood levels of TARC and on total IgE. Blood levels of TARC and total IgE remained unchanged after a 48-week course 
of mepolizumab, indicating that neither parameter was able to discriminate eosinophilic from noneosinophilic asthma. Interestingly, a very recent study on treatment of moderate to severe uncontrolled asthma with dupilumab, a fully human anti-IL-4 receptor $\alpha$ monoclonal antibody that blocks both IL-4 and IL-13 signaling, showed that patients who received dupilumab had greater reductions from baseline in peripheral blood levels of TARC and total IgE than patients who received matched placebo [33].

Serum periostin is increasingly interesting as a useful biomarker, although it did not correlate with sputum eosinophilia or eosinophilic airway inflammation [34]. In one study, serum free IL-5 was measured in asthma patients treated with mepolizumab but was not quantifiable at baseline in most patients [35], indicating that serum free IL-5 did not appear to be a useful biomarker for treatment with mepolizumab. Needless to say, integrated approaches involving clinical aspects, assessment of comorbidities, functional parameters, and biomarkers of inflammation are required in order to achieve as accurate an evaluation as possible of asthma control and follow-up.

In conclusion, our results showed a favorable long-term safety and efficacy profile for subcutaneous mepolizumab in Japanese patients with severe eosinophilic asthma.

\section{Acknowledgments}

The authors would like to thank Junya Maehata, BSc, for his assistance in assembling the figures, and Kenji Satoh, MPharm, for his assistance in the statistical analysis.

\section{Funding}

The authors declare that no funding was received for the present study.

\section{Conflicts of Interest}

The authors declare that they have no conflicts of interest.

\section{References}

1. Bousquet J, Chanez P, Lacoste JY, Barneon G, Ghavanian N, Enander I, et al. Eosinophilic inflammation in asthma. N Engl J Med. 1990;323:1033-9.

2. Wechsler ME, Fulkerson PC, Bochner BS, Gauvreau GM, Gleich GJ, Henkel T, et al. Novel targeted therapies for eosinophilic disorders. J Allergy Clin Immunol. 2012;130:563-71.

3. Flood-Page P, Menzies-Gow A, Phipps S, Ying S, Wangoo A, Ludwig MS, et al. Anti-IL-5 treatment reduces deposition of ECM proteins in the bronchial subepithelial basement membrane of mild atopic asthmatics. J Clin Invest. 2003;112: 1029-36.

4. Leckie MJ, ten Brinke A, Khan J, Diamant Z, O'Connor BJ, Walls $\mathrm{CM}$, et al. Effect of an interleukin-5 blocking monoclonal antibody on eosinophilic airway hyper-responsiveness and the late asthmatic response. Lancet. 2000;356:2144-8.

5. Pavord ID, Korn S, Howarth P, Bleecker ER, Buhl R, Keene ON, et al. Mepolizumab for severe eosinophilic asthma (DREAM): a muliticentre, double-blind, placebo-controlled trial. Lancet. 2012;380(9842):651-9.
6. Ortega HG, Liu MC, Pavord ID, Brusselle GG, FitzGerald JM, Chetta $A$, et al. Mepolizumab treatment in patients with severe eosinophilic asthma. N Engl J Med. 2014;371:1198207.

7. Jia CE, Zhang HP, Lv Y, Liang $R$, Jiang YQ, Powell $H$, et al. The Asthma Control Test and Asthma Control Questionnaire for assessing asthma control: systemic review and meta-analysis. J Allergy Clin Immunol. 2013;131:695-703.

8. Nair P, Pizzichini MM, Kjarsgaard M, Inman MD, Efthimiadis A, Pizzichini $E$, et al. Mepolizumab for prednisonedependent asthma with sputum eosinophilia. N Engl J Med. 2009;360:985-93.

9. Flood-Page P, Swenson C, Faiferman I, Matthews J, Williams $M$, Brannick $L$, et al. A study to evaluate safety and efficacy of mepolizumab in patients with moderate persistent asthma. Am J Respir Crit Care Med. 2007;176:1062-71.

10. Flood-Page PT, Menzies-Gow AN, Kay AB, Robinson DS. Eosinophil's role remains uncertain as anti-interleukin-5 only partially depletes numbers in asthmatic airway. Am J Respir Crit Care Med. 2003;167:199-204.

11. U.S. Food and Drug Administration. FDA approves Nucala to treat severe asthma. FDA News Release. 2015 November 4. Available from http://www.fda.gov/NewsEvents/Newsroom/ PressAnnouncements/ucm471031.htm. Accessed January 10, 2016.

12. http://www.ema.europa.eu/ema. Nucala authorization details [updated on 15/04/2016]. Available from:http://www.ema. europa.eu/ema/index.jsp?curl=pages/medicines/human/ medicines/003860/human_med_. Accepted May 5, 2016.

13. Shimoda T, Odajima H, Okamasa A, Kawase M, Komatsubara $M$, Mayer $B$, et al. Efficacy and safety of mepolizumab in Japanese patients with severe eosinophilic asthma. Allergol Int. 2017:66:445-51.

14. Lugogo N, Domingo C, Chanez P, Leigh R, Gilson MJ, Price $R G$, et al. Long-term efficacy and safety of mepolizumab in patients with severe eosinophilic asthma: a multi-center, open-label, phase IIlb study. Clin Ther. 2016:38:2058-70.

15. Global Initiative for Asthma (GINA). Global strategy for asthma management and prevention. http//www.ginasthma.org/local/ uploads/files/GINA_Report_2015. Accessed May 2015.

16. Kurosawa M, Yukawa T, Hozawa S, Mochizuki H. Recent advance in investigation of gene polymorphisms in Japanese patients with aspirin-exacerbated respiratory disease. Allergol Immunopathol (Madr). 2015;43:92-100.

17. Baldwin ED, Cournand A, Richards Jr DW. Pulmonary insufficiency; physiological classification, clinical methods of analysis, standard values in normal subjects. Medicine. 1948;27:243-78.

18. Berglund E, Birath G, Bjure J, Grimby G, Kjellmer I, Sandqvist $L$, et al. Spirometric studies in normal subjects. I. Forced expirograms in subjects between 7 and 70 years of age. Acta Med Scand. 1963;173:185-92.

19. Sugawara N, Yamashita T, Ote Y, Miura M, Terada N, Kurosawa M. TARC in allergic disease. Allergy. 2002;57:180-1.

20. Vandenplas O, Dramaix M, Joos G, Louis R, Michils A, Verleden $\mathrm{G}$, et al. The impact of concomitant rhinitis on asthma-related quality of life and asthma control. Allergy. 2010;65:1290-7.

21. Bousquet JI, Schunemann HJ, Samolinski B, Demoly P, BaenaCagnani $C E$, Bachert $C$, et al. World Health Organization 
Collaborating Center for Asthma and Rhinitis. Allergic Rhinitis and its Impact on Asthma (ARIA): achievements in 10 years and future needs. J Allergy Clin Immunol. 2012;130:1049-62.

22. Caminati M, Caimmi C, Dama A, Schiappoli M, Passalacqua G, Senna G. What lies beyond Asthma Control Test: Suggestions for clinical practice. J Asthma. 2016;53:559-62.

23. Thorley J. NICE issues draft guideline for asthma diagnosis. Lancet Respir Med. 2015;3:184.

24. Yancey SW, Keene ON, Albers FC, Ortega H, Bates S, Bleecker $E R$, et al. Biomarkers for severe eosinophilic asthma. J Allergy Clin Immunol. 2017;140:1509-18.

25. Bel EH, Wenzel SE, Thompson PJ, Prazma CM, Keene ON, Yancey SW, et al. Oral glucocorticoid-sparing effect of mepolizumab in eosinophilic asthma. N Engl J Med. 2014;371:1189-97.

26. Jatakanon A, Lim S, Kharitonov SA, Chung KF, Barnes PJ. Correlation between exhaled nitric oxide, sputum eosinophils, and methacholine responsiveness in patients with mild asthma. Thorax. 1998; 53:91-5.

27. Wagener $A H$, de Nijis $S B$, Lutter $R$, Sousa $A R$, Weersink EJ, Bel EH, et al. External validation of blood eosinophils, FE(NO) and serum periostin as surrogates for sputum eosinophils in asthma. Thorax. 2015;70:115-20.

28. Yang SY, Kim YH, Byun MK, Kim HJ, Ahn CM, Kim SH, et al. Repeated measurement of fractional exhaled nitric oxide is not essential for asthma screening. J Investig Allergol Clin Immunol. 2018;28:98-105.

29. Bonecchi R, Bianchi G, Bordignon PP, D'Ambrosio D, Lang $R$, Borsatti $A$, et al. Differential expression of chemokine receptors and chemotactic responsiveness of type $1 \mathrm{~T}$ helper cells (Th1s) and Th2s. J Exp Med. 1998;187:129-34.

30. Leung TF, Wong CK, Chan IH, Ip WK, Lam CW, Wong GW. Plasma concentration of thymus and activation-regulated chemokine is elevated in childhood asthma. J Allergy Clin Immunol. 2002;110:404-9.
31. Sekiya T, Yamada H, Yamaguchi M, Yamamoto K, Ishii A, Yoshie 0 , et al. Increased levels of a TH2-type CC chemokine thymus and activation-regulated chemokine (TARC) in serum and induced sputum of asthmatics. Allergy. 2002;57:173-7.

32. Hoshino $M$, Nakagawa $T$, Sano $Y$, Hirai K. Effect of inhaled corticosteroid on an immunoreactive thymus and activationregulated chemokine expression in the bronchial biopsies from asthmatics. Allergy. 2005;60:317-22.

33. Castro M, Corren J, Pavord ID, Maspero J, Wenzel S, Rabe KF et al. Dupilumab efficacy and safety in moderate-to-severe uncontrolled asthma. N Engl J Med. 2018;378(26):2486-96.

34. Izuhara K, Conway SJ, Moore BB, Matsumoto H, Holweg CT, Matthews JG, et al. Roles of periostin in respiratory disorders. Am J Respir Crit Care Med. 2016;193:949-56.

35. Pouliquen IJ, Kornmann O, Barton SV, Price JA, Ortega HG. Characterization of the relationship between dose and blood eosinophil response following subcutaneous administration of mepolizumab. Int J Clin Pharmacol Ther. 2015;53:1015-27.

- Manuscript received April 10, 2018; accepted for publication June 18, 2018.

\section{Motohiro Kurosawa}

\author{
Department of Allergy and Respiratory Medicine \\ Sutoh Hospital \\ 3532-5 Annaka, Annaka-shi \\ Gunma 379-0116, Japan \\ E-mail: motohiro@kl.wind.ne.jp
}

